\title{
INCOME POTENTIAL INDEX ANALYSIS OF HUNGARIAN CITIES AND TOWNS JÖVEDELEM POTENCIÁL INDEX VIZSGÁLAT A MAGYAR VÁROSOKBAN
}

\author{
Lilla Áldorfainé Czabadai ${ }^{1}$, Zoltán Topa ${ }^{2}$, György Áldorfai $^{3}$ \\ $1,2,3$ assistant lecturer \\ ${ }^{1,2,3}$ Szent István University, Faculty of Economics and Social Sciences, Institute of Regional \\ Economics and Rural Development \\ E-mail: ${ }^{1}$ aldorfaine.czabadai.lilla@gtk.szie.hu, ${ }^{2}$ topa.zoltan@gtk.szie.hu, \\ 3aldorfai.gyogy@gtk.szie.hu
}

\begin{abstract}
It is crucial to learn which factors could influence the income status of a region. In our study we try to collect basic data which well-represent the chosen topic, and more importantly, which are easy to access and are interpretable on smaller (for example settlement) territorial levels. Based on our hypothesis the received subsidies, the taxes paid by local people and the gross value added generated by local enterprises show strong correlation with the formation of the income status, and this hypothesis was tested for cities and towns in this paper.
\end{abstract}

\section{Összefoglalás}

A régiók és települések jövedelemteremtő képessége számos különböző tényező kölcsönhatására vezethető vissza. A cikkben bemutatott kutatás ezen tényezők közül vizsgált meg néhányat (támogatások, a helyi adók összege és a bruttó hozzáadott érték) azzal a céllal, hogy így a döntéshozók egyértelmübb képet kapjanak arról, milyen mutatókra érdemes koncentrálniuk döntéseik során, ha a lakosság jólétét szeretnék növelni.

Keywords: income, gross value added, subsidy, development

JEL classification: R10, R11

\section{LCC: HT388}

\section{Introduction}

It is imperative to explore historical changes in the spatial structure of Hungary to understand differences in income levels. The unique characteristics of the Hungarian settlement network were established approximately in the 1860s. The urbanisation wave, thanks to the industrial revolution, resulted in only the capital city's growth, both in qualitative and quantitative sense. There have been many plans and laws from the 1960s to balance out the monopolistic role of Budapest, which resulted in the appearance and strengthening of many larger and medium-sized rural towns. This relative deconcentration process caused the capital city's population to decline, and the appearance of agglomeration areas close to larger cities and towns. (Enyedi, 1984).

The notion of relieving cities and designing suburban areas appeared in many countries in Europe after the industrial revolution, in order to reorganise cities in a way that their functions are taken more into account (Le Corbusier, 1923), and also to create idyllic suburban areas (Howard, 1902). After the suburbanisation, desurbanisation and relative deconcentration processes in Hungary and in Europe as a whole, we can observe a new phenomenon: the urbanisation of the globalised world, which marks the beginning of a new concentration process (Szirmai, 2011; Enyedi, 2012). The new urban systems meant the concentration of global 
capital in larger cities and the increase of population number (and the appearance of metropolei) (Castells, 1972; Sassen, 1991).

In Hungary, the Economic Crisis also drew the economic and social processes in the agglomerations of Budapest and the rural cities towards a new type of concentration. Thanks to the changes in income levels, less and less people move to the suburban areas. Parallel to that, the number of people leaving those areas has increased. Increasing concentration can be observed during investigating income- and education levels and the language skills as well, because people with higher incomes and better education tend to live in the centres of cities. (Schuchmann-Váradi, 2015; Péli-Neszmélyi, 2015).

With regionally differentiated population comes regionally unequal income distribution. It is observable on an international level; that is why the European Union attempts to support convergence countries and regions by providing different subsidies, hoping that they would catch up with more developed countries.

The income situation tells many things about the population, because higher income levels allow the inhabitants of cities and villages to spend more on commodities, they can afford higher level healthcare and education services, and many other opportunities open up for people. In other words, it empowers the individuals and makes them feeling more secure, and in this way, they can live more meaningful and satisfying lives. Raising income levels, therefore, is not only beneficial for the economy (by boosting trade), but also by allowing people to spend their money on activities and goals, which they could not before.

The income situation is a basic indicator that tells much about the opportunities of the population; therefore, the data required for their investigation are collected regularly and precisely by central governments. In Hungary it is collected by the Hungarian Central Statistical Office (KSH); some of their international counterparts are the United States Census Bureau in the US, the National Statistics Office (ONS) in the United Kingdom, the Federal Statistical Office (Destatis) in Germany. They collect data on the income levels of their respective countries. For European and international levels, the European Committee (Eurostat) and the OECD are analyzing the most user-friendly and organized country (and sometimes regional) level records available to users. The most common indicator of income levels in the abovementioned statistical systems is the household income level.

However, it is not sufficient to analyse only the households if we are to conduct a research from economic- and rural development approaches. Regional analyses must take into account many historical, economic and social theories and factors related to the topic of the investigation. When analysing the income levels, we must discuss the origin of differences between settlements (and settlement types), the urbanisation processes, competitiveness, business location theories, well-being, employment, social processes (migration), or even the effects of government support (Káposzta et al, 2014).

The development levels of countries are measured by their GNI, while regions are measured by using GDP (European Commission, 2015). Experts have been debating for decades about the usage and content of GDP, as an indicator measuring economic development. It is clear that it properly represents income levels; however, it cannot be applied for measuring competitiveness or social welfare, due to its lacking nature (Stiglitz et al, 2010).

Social Progress Index, published in 2015, is a suitable alternative to measure well-being (Csath, 2016; Porter et al, 2015). It investigates several indicators (e.g. ones related to basic services, health-care and human rights) within three categories (basic human needs, the bases of wellbeing and opportunities), which are beyond indicators illustrating economic development. The 
content of the index was changed (expanded) in 2016; therefore, now it examines even more countries with more indicators (Social Progress Imperative, 2016).

We can find new elements of development by approaching from country level towards local spaces, and investigating competitiveness using the Regional Competitiveness Index (Csath, 2016; Annoni-Kozovska, 2010). Beside the governmental, infrastructural, macroeconomic and human resources data, we can observe data related to innovation, which contains the technological readiness and innovation abilities of a region. Innovation activity and income levels show positive correlation, which means that in those areas, where intensive knowledgebased activities are carried out, and the proportion of $R \& D$ spending is high, we can see higher income levels.

The increasing $R \& D$ spending and the expansion of innovation is generally more common in regions where we can find institutions of higher educations, or the concentration of companies (business clusters, business incubators, etc.). Companies provide $80-90 \%$ of the jobs in the developing countries; furthermore, they produce approximately $60 \%$ of the GDP. These proportions are very similar in Hungary, because the territorial inequalities (resulted by the first large wave of urbanisation) increased after the political transition in 1989-1990. The seven statistical regions created as a requirement for the accession to the EU do not cover homogenous territories, and that is one of the reasons why the development level of the capital city distorts the development data of the Central-Hungarian region in a positive way (Budapest produces approximately $40 \%$ of the Hungarian $\mathrm{GDP}^{1}$ ). In this case, despite the criticism mentioned before, GDP is a very meaningful indicator; Budapest would belong to the 25 best-performing regions in the European Union. The high level of regional disparities is well-shown by the fact, that four regions out of the seven belong to the 20 poorest regions of the EU: Northern-Hungary, Northern Great Plain, Southern Great Plain, Southern Transdanubia (Tóth, 2016).

Purchasing power is a sufficient indicator for the economic development and income level of a region' population. As an example (or motivation) we use one of the works of GeoX Kft., a company dealing with regional data collection and processing created a map about the purchasing power of the Hungarian settlements, using data from 2014 which year is the closest date to our analysis when this map is existing (Figure 1.). The Települési Vásárlóerő Adatbázis (Settlement-level Purchasing Power Database) contains and applies basic data and calculated indicators for the income situation (income from work, social income, calculated gross and net income) and for consumption spending (e.g. food, clothing, home maintenance, transportation, health care, education, etc.) per capita, in Hungarian Forint (HUF), for every settlement, in a unified way (GeoIndex, 2016).

This paper discusses an index created by utilising knowledge from literature review and own experience, which is, similarly to the settlement level purchasing power, able to illustrate the income potential of Hungarian cities and towns in a graphical way.

\footnotetext{
${ }^{1}$ Due to the differences in development levels, the Council of Pest county voted for the separation of Budapest and the rest of Pest county in January 29th, 2016.
} 


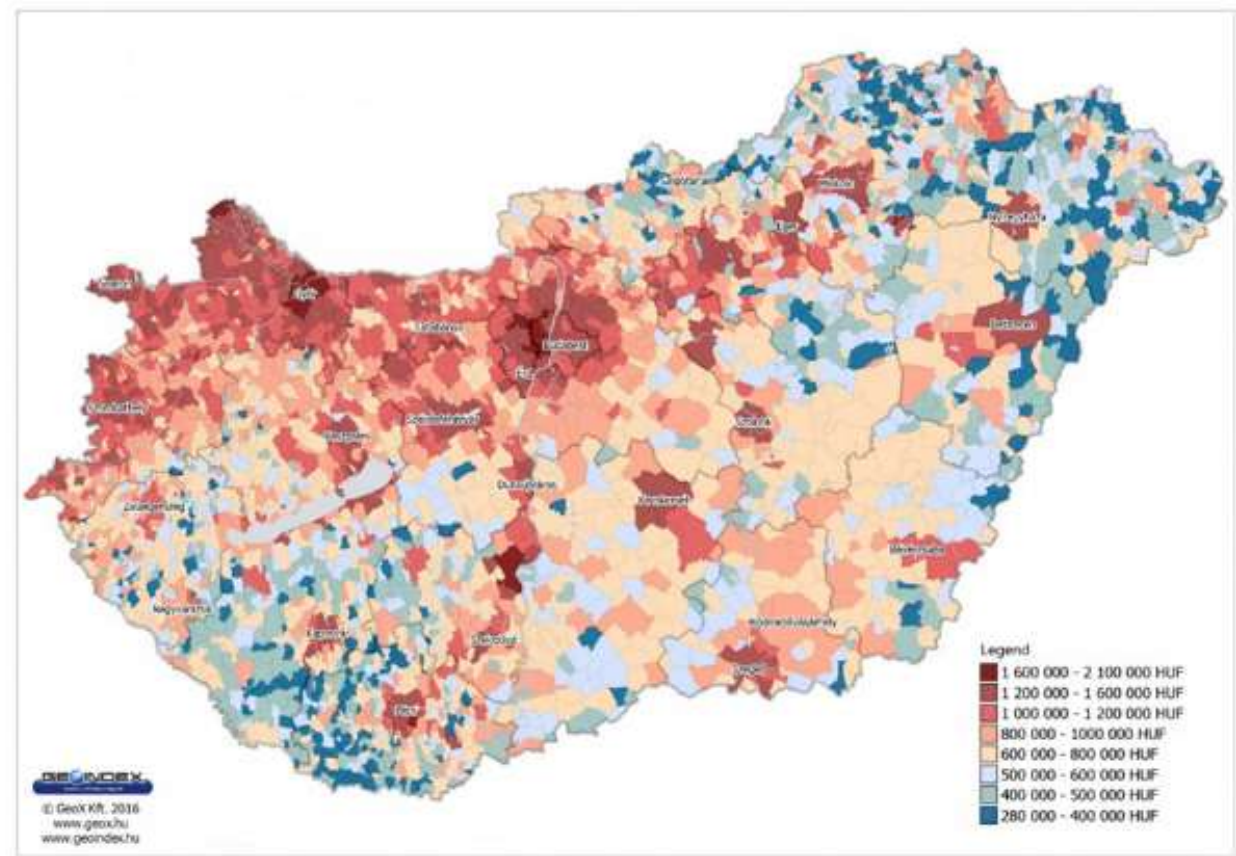

Figure 1: Settlement level purchasing power 2014

Source: Települési vásárlóerő adatbázis, 2016

\section{Material and methods}

As a first step, we chose datasets based on literature and on our own experience, and then they were selected based on their relevancy to the research topic. After the data-gathering process, the result was a dataset consisting of 30 indicators, which were collected from all years between 2007 and 2013. Due to the lack of data before 2009 and after 2013 we experienced in the case of some indicators, the analysed time period was decreased to the years between 2009 and 2013 . The chosen territorial unit for our investigation was the settlements in Hungary, which fall into the category of cities and towns, according to Hungarian laws. We intended to prove the applicability of our methodology and the need to establish an information system to support it. As a result of our efforts, we collected 30 (standardised) indicators for 346 cities and towns and for 5 years.

After collecting the data, correlation analyses were conducted, focusing on the years investigated, in order to observe the relationship between income levels and other indicators (and if there are any, how strong they are), and to see whether the correlation can be observed in every year, or not.

Based on the values of the correlation the type of the linear relationship was categorised into a five-level scale, based on Huzsvai and Vincze, which categorisation is illustrated on Table 1.

Table 1: The type of linear correlation between variables

\begin{tabular}{|l|c|}
\hline \multicolumn{1}{|c|}{ The strength of the correlation } & The value of $\mathbf{~ r}$ \\
\hline There is no correlation between the variables & $-0,25<r<0,25$ \\
\hline Weak stochastic correlation & $-0,5<r<-0,25$ or $0,25<r<0,5$ \\
\hline Moderate stochastic correlation & $-0,75<r<-0,5$ or $0,5<r<0,75$ \\
\hline Strong stochastic correlation & $-1<r<-0,75$ or $0,75<r<1$ \\
\hline Perfect correlation & $r=-1$ or $r=1$ \\
\hline
\end{tabular}

Source: The authors' own editing based on Huzsvai et.al (2012) 
Since the direction of the relationship does not indicate the direction of dependent and independent variables, but the direction of the correlation, the classification of Huzsvai and Vince was used.

In order to expand the research, an index was created during the correlation analysis from the data - indicators - showing strong and moderate stochastic correlation, to find out which indicators influence the income levels in the districts. This index was called 'Income Potential Index'. During the creation of this index a simple indexing method, the minmax normalisation, during which the indicators are weighted by their correlation values. During the minmax normalisation different indicators with different units of measure are transformed to a certain range (during which the distribution remains the same). The following formula was used:

$$
X^{\prime}{ }_{i}=\frac{\sum_{i=1}^{N} r_{x} * \frac{x_{i} * \min _{x}}{\max _{x} * \min _{x}}}{\sum_{i=1}^{N} r_{x}} * 100
$$

where the $\min _{x}$ is the lowest, while $\max _{\mathrm{x}}$ is the highest value of the indicator, and $\mathrm{r}_{\mathrm{x}}$ marks the correlation value of income levels and the selected indicator.

The data gained by the analyses were illustrated on maps by using the QGIS software.

\section{Results}

The results of the most important (moderate- or strong stochastic) correlations are illustrated by Table 2. As seen on the table, there is one strong (knowledge-intensive services), two strongly moderate (number of operating enterprises, number of unemployed people), two moderate (local taxes, the length of the fastest way connecting the settlement with the capital) and three weak (gross value added, high-tech processing industry, medium high-tech processing industry) kinds of stochastic correlation was found between the income levels and the other 29 indicators.

Table 2: The values of coefficients resulted by the correlation analysis

\begin{tabular}{|l|r|r|r|r|r|}
\hline & \multicolumn{1}{|c|}{$\mathbf{2 0 0 9}$} & \multicolumn{1}{|c|}{$\mathbf{2 0 1 0}$} & \multicolumn{1}{c|}{$\mathbf{2 0 1 1}$} & \multicolumn{1}{c|}{$\mathbf{2 0 1 2}$} & $\mathbf{2 0 1 3}$ \\
\hline Gross value added & 0,447 & 0,487 & 0,445 & 0,436 & 0,453 \\
\hline $\begin{array}{l}\text { The length of the fastest way connecting the } \\
\text { settlement with the capital }\end{array}$ & $-0,495$ & $-0,498$ & $-0,554$ & $-0,544$ & $-0,538$ \\
\hline Local taxes & 0,569 & 0,577 & 0,582 & 0,579 & 0,573 \\
\hline High-tech processing industry & 0,508 & 0,482 & 0,492 & 0,424 & 0,379 \\
\hline Medium high-tech processing industry & 0,403 & 0,384 & 0,446 & 0,419 & 0,414 \\
\hline Knowledge intensive services & 0,370 & 0,763 & 0,767 & 0,738 & 0,720 \\
\hline Number of operating enterprises & 0,716 & 0,699 & 0,699 & 0,666 & 0,641 \\
\hline $\begin{array}{l}\text { The number of registered unemployed } \\
\text { people }\end{array}$ & $-0,697$ & $-0,712$ & $-0,720$ & $-0,711$ & $-0,668$ \\
\hline
\end{tabular}

Source: The authors' own editing based on own analysis

As we can see in the table, indicators show different levels of stochastic relationship with income, with a fluctuation between them in different years. Therefore, we partly accept the basic hypothesis of our research; namely, that income levels show close correlation with many other indicators, and this correlation remains the same in later years. From the abovementioned 8 indicators we received normalised data weighted by their correlation value for city and town levels, by using the methodology discussed above. Based on the methodology the values could be varied on a scale from $0-100$, which values can be categorised into five groups (Table 3 ). 
Table 3: The categorisation of normalised data weighted by correlation values

Source: The authors' own editing based on own analysis

\begin{tabular}{|c|c|c|}
\hline Colour code & Name & Value \\
\hline & Very low & $0-14,99$ \\
\hline & Low & $15-29,99$ \\
\hline & Average & $30-44,99$ \\
\hline & High & $45-59,99$ \\
\hline & Very high & $60-100$ \\
\hline
\end{tabular}

The results are illustrated on maps for every investigated year (Figure 2).

It was found, that there was significantly positive change in 48 cities, positive change in 256 , slight change in 37, negative change in 3 and significantly negative change in 2 cities in the investigated time period. The research found the urban areas with the worst income potential in Northern-Hungary (Nagyecsed), but we found one of the best value in this region (Mátészalka) as well. The other high income potential level values are typical in Central-Hungary. There was almost 63 index point difference between Budapest, the one with the best values and Nagyecsed, the one with the worst values .This result well illustrates that there are significant regional differences in Hungary regarding to the factors affecting income levels.

We discovered the following main results by analysing the maps and the datasets behind them.

It is striking that only three settlements (Budapest and its immediate west agglomeration neighbours, Budaörs and Törökbálint) fell in the very high-income category in all five years. It can be seen that from 2009 to 2010, the number of high-income cities has increased (from 7 to $44)$, which is most noticeable in the wider urban agglomeration. This trend continued to increase for 2011 (51); Cities and towns with high income potentials were situated mainly in the western part of the country. At the same time, it can be noticed that some of the larger cities and towns have also developed in the north-eastern, southern and south-western parts of the country.

In 2012 (47) and in 2013 (42), we noticed a slight decline in the number of high-income cities and towns. The year 2009 stands out for settlements with the lowest and low income potential, since they had the highest number in the year under review. Over the next few years a similar trend may be observed in the case of high income cities, but with a larger volume. In other words, this means that in 200935 settlements were the lowest and 203 settlements in the low income category in 2010 were 27 in the former and 146 in the latter group. In 2011, the lowest values were generated by 15 settlements, with 136 cities with low incomes, falling again to 14 in the worst category by 2012, and 141 worst in the worst category.

In the last investigated year, 11 very low potential and 147 low-income settlements were added to the map. From year to year, the number of settlements with average income potential increased between 2009 and 2013. The average number of 98 average income-averaged cities in the first year under review grew to 128 in 2010, 139 in 2011, followed by a slight decrease of 135 (135) in 2013, to 144 in 2013. 


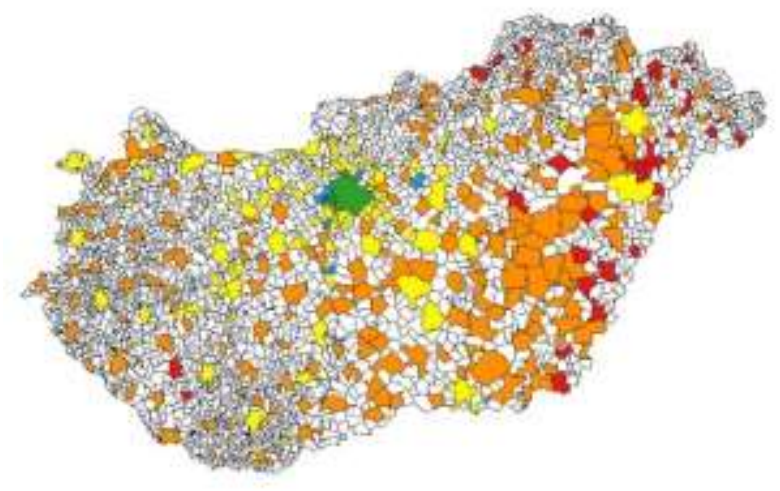

2009

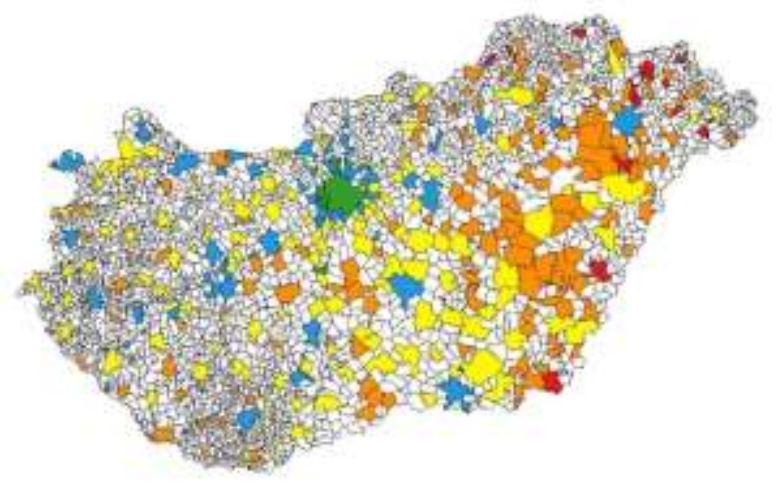

2011

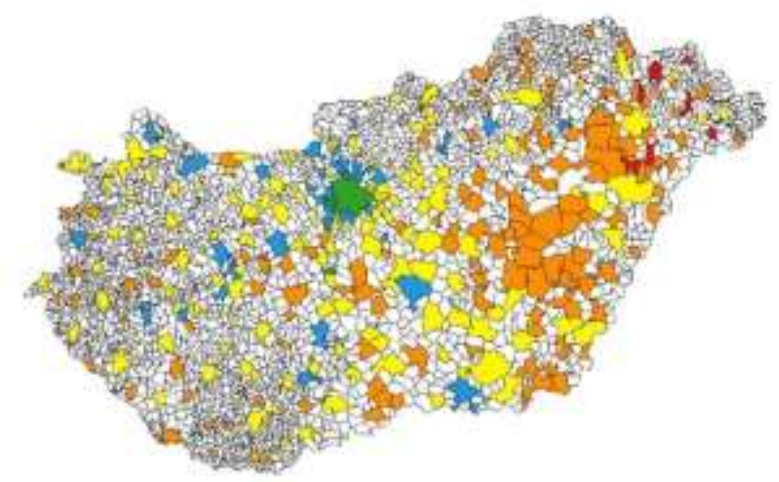

2013

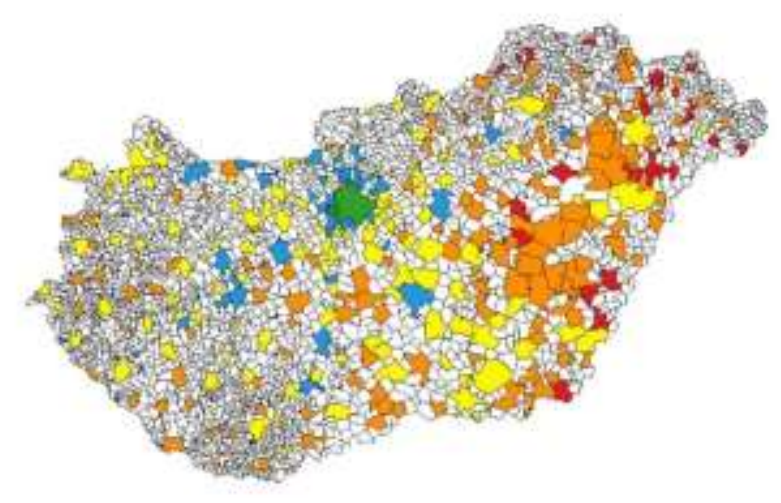

2010

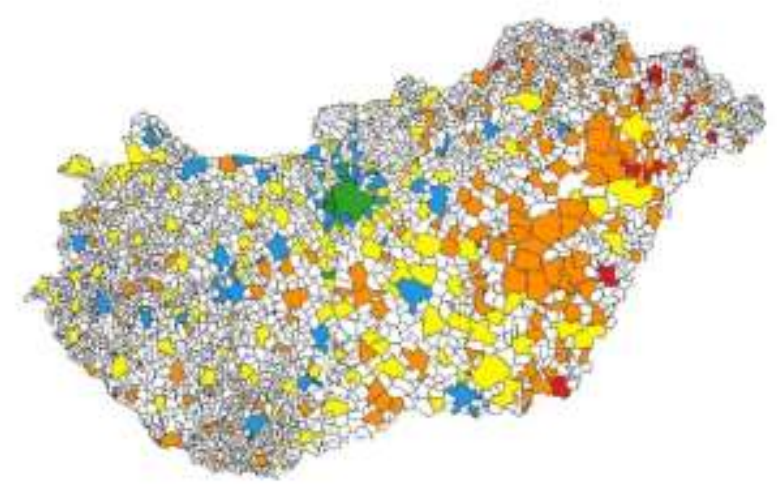

2012

\begin{tabular}{|c|c|}
\hline Categories & Value \\
\hline Very low & $0-14,99$ \\
\hline Low & $15-29,99$ \\
\hline Average & $30-44,99$ \\
\hline High & $45-59,99$ \\
\hline Very high & $60-100$ \\
\hline
\end{tabular}

Figure 2: The trends of the Income Potential Index throughout the investigated years Source: the authors' own editing based on own analysis by using QGIS

\section{Conclusion}

We can draw several conclusions by examining trends in the number of cities with the lowest and highest income potentials. The results of 2009 are likely to indicate the effects of the economic crisis. As of 2010, the growth observed in the number of average and high-income cities, and the decrease in the low and lowest categories, indicated a shift in the east-west direction. This means that the number of areas with high potential in the western part of the 
country has increased and that the number of low-income areas has decreased more than in the eastern regions. This can be traced back to the historically-occurring West-East disparity already mentioned in the literature. Typically, the map of settlements of low-category settlements is well illustrated by the farm structure of the Great Plain. Its unfavorable situation is also due to historical reasons, but the lack of treatment of the problem hinders the development of the income situation of the lowland towns. High-income settlements (outside the Budapest agglomeration) are typically located along the lines of motorways M1, M3, M5, M7 and Lake Balaton. Based on the results, the absence of significant factors influencing the income potential index that we determined at the beginning of this paper (the presence of knowledge-intensive services, the number of registered unemployed and the number of active enterprises) causes significant differences in the income situation of some cities and towns, so it can be concluded that territorial differences in Hungary occur regarding to the income potential as well, and they do so in such way as determined by literature and by our experience.

However, it is noteworthy that if we look at the changes, that have taken place over the observed five years, the results are different in each settlement. The most striking change is that Budapest is at the end of the line, while a Northern-Hungarian small town, Rétság, took the first place. The reason for this is that, for example, the high values of Budapest, if only slightly, but declined, but the Rétság figures increased considerably compared to the original average value and to itself. This can be observed in a number of settlements that motivate the pursuit of the following research to find out how the development (or decline) of settlements' income levels has evolved in recent years.

A very important finding of the study was that unlike our hypothesis the received subsidies, the taxes paid by local people and the gross value added generated by local enterprises do not show strong correlation with the formation of the income status, but income levels show strong correlation with knowledge-intensive services and strongly moderate correlation with the number of operating enterprises and the number of unemployed people (Table 2.). It means that central and local governments should keep focusing on unemployment, as a cardinal issue, but should concentrate even more on ensuring the creation of more enterprises (for example, by providing good business environment for them). Tourism could be a key sector in Hungary, since the country has significant untapped potential in this field. Domestic tourism however requires a modern management and operating system to be established, since the global trends, the changes of tourism market and the intense competitions (Nagy - Virág, 2014). Tourism has been a dynamically growing sector globally, and it is an way to strengthen the multifunctional nature of rural areas, where agriculture is still a prominent income generating activity, but it has been gradually losing its significance and the competitiveness of this sector is relatively weak (Káposzta et al, 2008).

Also, knowledge-intensive services are of key importance - not only because of the fact that they create high added value, but also because they need highly educated people, who, when settled down in a settlement, can initiate even development programmes as vital members of local communities (Kassai, 2017).

\section{References}

1. Annoni P. - Kozovska K. (2010): EU Regional Competitiveness Index 2010. European Commission Joint Research Centre, Publications Office of the European Union, Luxembourg, 28-47.p., Available at: http://publications.jrc.ec.europa.eu/repository/handle/JRC58169. [Downloaded: 2017.03.12.] 
2. Castellis M. (1972): La question urbaine. Transleted by Alan Sheridan in 1977. Edward Amold Ltd., London, 493 pp.

3. Csath M. (2016): A regionális fejlettség mérése társadalmi-gazdasági mutatók alapján. Pest megyei esettanulmány. In: Csath M. (ed.): Regionális versenyképességi tanulmányok. Budapest, NKE Szolgáltató Nonprofit Kft., 73-107. p.

4. Enyedi Gy. (1984): Az urbanizációs ciklus és a magyar településhálózat átalakulása, Értekezések-emlékezések. Budapest, Akadémiai Kiadó, 14-19. p.

5. Enyedi Gy. (2012): Városi világ. Budapest, Akadémiai Kiadó, 186 pp.

6. European Commission (2015): Regional Policy - Inforegio: Which regions are affected? Available at: http://ec.europa.eu/regional_policy/archive/policy/region/index en.htm. [Downloaded: 2017.03.12.]

7. GeoX Kft. (2016): GeoIndex, Települési vásárlóerő 2014. Available at: http://www.geoindex.hu/adatbazisok/telepulesi-vasarloero/. 2017.03.13.]

8. Howard E. (1902): Garden cities of To-morrow. London, Swan Sonnenschein \& Co., $195 \mathrm{pp}$.

9. Huzsvai L. - Vincze Sz. (2012): SPSS-könyv, Seneca Books Kiadó, 325 pp.

10. Káposzta J. - Nagy A. - Nagy, H. (2014): Efficiency of Hungarian regions in using the development funds for touristic purposes. Regional Economy. South of Russia. Vol. 4. No. 6. 33-39. p.

11. Káposzta J. - Tóth T. - Singh M K. (2008): Perspectives on regional economic development policy and strategy. Management and Behaviour in Organizations. Vol. 2: Selected Proceedings of the First International Conference on Social Sciences. Izmir, Yasar University, Paper 5. 9 p. (ISBN:978-605-5741-01-3)

12. Kassai Zs (2017): A közösségi aktivitás jellemzői Heves megye két hátrányos helyzetü településén. Pro Scientia Ruralis. Vol. 2. No. 1. 35-47. p. Available from: http://psr.pahru.ro/images/psr/2017I/PRS-17-1-35-47.pdf.

[Downloaded: 2017.02.22.]

13. Le Corbusier (1986): Towards a New Architecture (Vers une Architecture), Translated from the thirteenth edition and with an Introduction by Frederick Etchells. New York, Dover Publications Inc., 318 pp.

14. Nagy A. - Virág Á. (2014): Destination management in Hungary. Estnik Apk Stavropolya / Agricultura Bulletin of Stavropol Region. Vol. 1. No. 1., 41-44. p.

15. Péli L. - Neszmélyi GY. I. (2015): Territorial Differences Of Rural Cities And The Development Of Transport Infrastructure In Hungary. Romanian Review Of Regional Studies: Journal of The Centre For Regional Geography. Vol 11. No. 2. 69-84. p.

16. Porter M. - Stern S. - Green M. (2015): Social Progress Index 2015. Washington, Social Progress Imperative, 158 p., Available at: http://13i8vn49fibl3go3i12f59gh.wpengine.netdna-cdn.com/wpcontent/uploads/2016/05/2015-SOCIAL-PROGRESS-INDEX_FINAL.pdf. [Downloaded: 2017.03.10.]

17. Sassen S. (1991): The Global City: New York, London, Tokyo. New Jersey, Princeton University Press, 22-34. p.

18. Schuchmann J. - Váradi Zs (2015): A magyar nagyváros-térségek társadalmidemográfiai szerkezete. In: Szirmai Viktória (ed.): A területi egyenlőtlenségektől a társadalmi jól-lét felé. Székesfehérvár, Kodolányi János Főiskola. 111-130 p. 
19. Stiglitz E. J. - Sen A. - Fitoussi J. (2010): Mismeasuring Our Lives: Why GDP Doesn't Add Up. Report by the Commission on the measurement of Economic Performance and Social Progress, Available at: http://library.bsl.org.au/jspui/bitstream/1/1267/1/Measurement of economic perfor mance and social_progress.pdf. [Downloaded: 2017.03.11.]

20. Szirmai V. (ed) (2011): Urban Sprawl in Europe: Similarities or Differences? Budapest, Aula Kiadó. 280 p.

21. Tóth R.,(2016): A magyarországi kis- és közepes vállalkozások regionális különbségei. In: Csath M. (ed.): Regionális versenyképességi tanulmányok. Budapest, NKE Szolgáltató Nonprofit Kft., 143-179. p. 